\section{International Scientific Journal Theoretical \& Applied Science}

\author{
p-ISSN: 2308-4944 (print) e-ISSN: 2409-0085 (online) \\ Year: 2014 Issue: 12 Volume: 20 \\ Published: $30.12 .2014 \quad$ http://www.T-Science.org
}

SECTION 31. Economic research, finance, innovation, risk management.
Inna Vladimirovna Lipatova

Candidate of economic science, Docent, a chair of "Taxes and taxation"

Department for academic affairs at the Financial

University under the

Government of the Russian Federation lipinna@1and.ru

Marina Konstantinovna Krivtsova the forth-year student, the Chairman of Scientific Student Society of Public and Municipal Administration faculty at the Financial University under the Government of the Russian Federation marinstar@bk.ru

Ivan Valerievich Kodolov the forth-year student, the Deputy Chairman of Scientific Student Society of Public and Municipal Administration faculty at the Financial University under the Government of the Russian Federation vanqakodolov@gmail.com

\title{
TRENDS IN FORMATION OF TAX SYSTEM IN TERMS OF GLOBALIZATION
}

Abstract: In this work the factors affecting on changes of the tax system are listed. Moreover, the difference in tax rates as a factor of influence on investments flows is mentioned. The author emphasizes on a new phenomenon in the tax field which is international cooperation.

Key words: tax system, globalization, fiscal government sovereignty, adaptation, coordination, harmonization.

Language: English

Citation: Lipatova IV, Krivtsova MK, Kodolov IV (2014) TRENDS IN FORMATION OF TAX SYSTEM IN TERMS OF GLOBALIZATION. ISJ Theoretical \& Applied Science 12 (20): 13-15. doi: http://dx.doi.org/10.15863/TAS.2014.12.20.4

Tax system can be determined as the totality of following components:

- all taxes which are raised by the government;

- principles, forms and methods of establishing, changing and cancelling these taxes, methods of its calculation and levying;

- forms and methods of tax control and responsibility for tax legislation infringement.

Modern tax system has its long history. It has been influenced by different factors: objective and subjective. Among objective factors are social evolution and social events as a whole. And political events, wars, acts of God are examples of subjective factors. [9]

In twentieth century tax system was characterized as a system with preconceived taxes. In those times direct forms of taxation prevailed due to the widespread introduction of income taxation. The rationalization of indirect taxation was implemented: the range of excisable products was reduced, turnover tax was introduced which later in the second half of twentieth century in Europe transformed into value added tax and in USA and Canada - into sale tax. [10]

Now globalization, the development of communicatory technologies and electronic commerce and increased mobility of factors of production has become distinguishing features of New Millennium. They have strengthened the contradictions between global economy and local nature of taxation. As a result the necessity of modification of modern tax systems has occurred. [6]

V. Tanzi summarized the list of factors which lead to the changes in existed tax systems. They are the following:

- increase in volumes of Internet trading;

- spread of using electronic money by anonymous accounts;

- international transactions inside the companies and transfer price formation;

- complexity of finance capital taxation;

- spread of offshore manufacturing;

- derivative financial instruments; 
[7]

- increase of international activity of citizens.

Under the influence of these factors the task to determine potential tax base which is available for collecting taxes within separate country has become much more complex. As a result fiscal government sovereignty is reduced significantly and loses its inherent features. [3]

Nowadays the problems of taxation, of national tax policy and its unification which often does not coincide with national interests become more acute. National interests in this case are directed to the growth in their own competitiveness which contents tax competition.

The growing intensity of informational goods and capital let countries by decrease in tax rates attract additional financial resources in the given tax jurisdiction, and thus stimulate tax competition. Difference in income tax rates in different countries becomes a new factor which influences greatly routes of investment flows. If the rate of tax on profit in neighboring country is much lower than in own, then entrepreneur gets a motivation to transfer his production to that country (a chilling moment - costs of redeployment) hence competition between countries. [2]

In that way it is clear that the globalization stimulates competition between countries in reduction of both direct and indirect costs, so that it allows supporting constant race of tax reduction as whole, losses of which inevitably bears the local population: governments reduce expenses on keeping jobs in the budget sphere, including education, medicine and social protection. [1]

Realized the scales of threat, which globalization of economic space creates for the effective functioning of national tax systems, governments increasingly resort to international cooperation in tax field. As a result of such cooperation a new phenomenon has formed - gradual convergence of national tax systems, basic principles of taxation and approaches to the formation of national tax policy. Such a convergence can take a shape of tax adaptation, tax coordination and harmonization. [4]

Adaptation in taxation area consists of monitoring the tax systems and tax reforms of different countries with further borrowing of those measures and mechanisms, which can better protect economic interests. During last decades adaptation processes gained impressive speed. This can be demonstrated on the example of income taxation of natural person. Among Central and Eastern European countries spread rapidly practice of denial from progressive mechanism of income taxation of natural persons by changing it on proportional tax rate - for the period from 1994 to 2008 such changes were implemented in 12 European countries. [5, 8]

Coordination means cooperation of tax authorities of different countries for studying the experience of solving individual problems in tax sphere and exchange of information about tax payers, first of all for counteraction of tax evasion.

Harmonization in sphere of taxation consists in convergence of national tax systems on the base of following the complex of internationally agreed rules. However the process of harmonization in area of taxation faces significant barriers, caused not only by essential distinctions, but also by different levels of socio-economic development, and the reluctance of countries to limit the state fiscal sovereignty. Spread enough is the harmonization of certain regulations of the tax legislation on the state level through bilateral agreements. [4]

So it is possible to make a conclusion that in most countries trends in the formation of tax systems in the XXI century are:

First, to maintain a current tax competition it is necessary to refuse privileges to various categories of taxpayers, objects of taxation, due to this decrease tax rates and thus try to keep the charge base, and secondly, the need arises to transfer the charge base from the profit on consumption and material property, i.e. to the prevalence of property taxation.

\section{References:}

1. Gorelko A, Gorelko M (2011) World finance crisis and problems of tax policy enhancement / Tax and finance No.8 (45), August, 2011.

2. FitzGerald V (2002) International Tax Cooperation and Capital Mobility, Cepal Review , 77.

3. Glyn A (2006) Capitalism Unleashed: Finance, Globalization and Welfare. New York: Oxford University Press.
4. Ped IV (2010) Evolution of national tax systems in terms of world economy globalization/ Tax and finance law No.5, 2010.

5. Picciotto S (2007) The International Crisis of Income Taxation: Combating tax havens, capital flight and corruption, Presentation to Critical Legal Conference (Kent, UK), February. 
6. Radchenko V (2014) Globalization and taxes in the $21 \mathrm{st} \quad$ century. Available: http://www.cato.ru/pages/69?idcat=393\&parent id $=392$

7. Tanzi V (2005) Globalization, Tax System, and the Architecture of the Global Economic System / Vito Tanzi. -Inter-American Development Bank-2005, pp.2.

8. Vasilieva MV (2008) World experience in reforming modern taxation systems of the developed countries. Taxes and Financial Law. 2008. No.7.

9. Vladimirova IG (2014) Globalization of world economy: issues and consequences. Management in Russia and abroad.

10. (1998) The basis of taxation / Edited by doctor of economic science, professor Pavlova, L.I.Goncharenko, D.K.Grunina, N.P.Melnikova. Moscow: Financial Academy under the Government of Russian Federation, pp. 32. 